ISSN 1112-9867

Available online at http://www.jfas.info

\title{
ADAPTATION OF THEATRICAL ELEMENTS OF NEZAMI GANJAWI A CASE STUDY ON THE BALLAD OF KHOSROW AND SHIRIN
}

\author{
M. Amiri
}

National Zabol University Faculty Member, MA Theater Producer

Published online: 15 May 2016

\begin{abstract}
Nezami was one of the most skilled writers of Persian poems and ballads, not only he had his own signature style but the impact of his style is evident on the works of poets not contemporary to him. Nezami had sufficient knowledge about the popular sciences of his time (literary sciences, astronomy, Islamic sciences and the Arabic language), and his vast knowledge is evident in his body of work. He could be considered as a master playwright, because his masterpiece "The Ballad of Khosrow and Shirin" is amongst the best plays ever written, thus every adaptation of this masterpiece might result in an original and good quality creation. This paper tends to analyze some theatrical adaptations of the mentioned ballad, in order to examine their types of approach to this invaluable play.
\end{abstract}

Key Words: Ganjawi, theatrical elements, Khosrow and Shirin, adaptation

Author Correspondence, e-mail: art.amiri@uoz.ac.ir

doi: http://dx.doi.org/10.4314/jfas.v8i3s.265

\section{INTRODUCTION}

What makes Nezami's poems so unique is his storytelling ability in them, even though his predecessors have used this style before, but Nezami succeeded in creating a rich and meaningful story. Therefore, a thorough investigation of Nezami's writing techniques is necessary in order to understand the key to his success in telling of traditional stories, and might make way for a comparative study on them, 
Hakim Jamal Alddin Abu Muhammad Elias Bin Yusuf Bin Zakki also known as Nezami Ganjawi, was one of the most prominent Persian story tellers and masters of ballad writing, $\mathrm{He}$ was born on the year 525 in the town of Ganjah and stayed there (except for a brief journey to a town nearby Ganjah due to receiving an invitation from Qezel Arsalan) until the day of his death on the year 614 or 616 . As it is obvious from his poems, his talent was not restrained to poetry, but he had a special fondness for literary techniques, history and stories since his youth, thus he pursued and completed his education. His most famous work would be the "Five Treasures" or Khamsah, which its first mathnawi is "The safe of Secrets" and its best would be "Khosrow and Shirin" The mathnawi of Khosrow and Shirin" which is the subject of this study consists of 6500 verses. This ballad (mathnawi) tells a love story between Khosrow Sasaani and a Christian girl named Shirin Shahdokht, Nezami has finished this ballad by the year 576, and has dedicated it to Atabak Shams Alddin Muhammad Jahan Pahlawan Ben Ildagz.

The story telling literature can be defined as any kind of story that its fantastical and made up aspects would be prevail its historically accurate ones (Mir Sadeqi, 2009, P: 33). The story telling literature has different sub branches such as: tales, romances, novels and short stories, each of these sub branches have different characteristics that are unique to them which reviewing them requires knowing. Nezami's stories and especially "Khosrow and Shirin", have the characteristics of traditional and ancient stories. Therefore, "Khosrow and Shirin" is actually a story rather than a poem, because most characteristics of stories can be found in it. Nezami's style is accurate and magical, his detailed descriptions, cliff hangers, use of symbolisms and shifting the style of storytelling have made this story similar to its modern counterparts. Proving the mentioned characteristic requires the thorough investigation of the story "Khosrow and Shirin".

The principles of story analysis are based on the elements used in the story, and the story assessment is based on the application of those elements within the story. Prominent story elements have a crucial role in the assessment and analysis of the story.

Nezami, along with Ferdowsi and Sa'die was amongst the pillars of Persian poetry. Even though story telling within a poem was not started with Nezami, however he was the only one who was able to improve symbolic poetry. Different factors make up for Nezami's successful storytelling. The accurate choice of words, the rhythmic verses, use of creative compounds, invention of new and novel meanings, good description which derives from a strong imagination, accuracy in describing the natural sceneries, night and day and castles and the impressive use of metaphors 
and analogies, are amongst the mentioned factors. Factors that made his stories so popular that many poets after him attempted to mimic his style, but failed in doing so.

\section{Study Method}

The method used in the conduction of this study consisted of the analysis of the semantics signs of story's elements and their way of application in the story based on the analytic approach of phenomenology in order to analyze the elements and their way of applications in the story. Based on the principles and hypotheses of this method and approach, each sign has an applicatory correlation with other signs and elements within the story which makes it extraordinary and takes it to an analytic - visual level. No sign or element could make any sense solely; rather it is the correlation between elements which creates the ideal theatrical mode.

\section{The Antecedents of Plays (Theater) and Playwriting in Iran}

The emergence of plays and playwriting in Iran dates back to the pre-Islam era. The ancient forms of Persian plays were rooted in religious teachings. The earliest forms of plays were the Zoroastrian ceremonies in which Maqs would gather and sing the songs written in the Avesta while dancing in groups. In ancient Persia, theater-like ceremonies were carried out in the occasion of mourning and victory, such as Kin Syawosh which was a ceremony in honor of Syawosh's death carried out in the north east localities of Iran until the fourth century, other ceremonies in that form such as Kin Iraj, Mourning for Zaal, Jamshid Religion and crying for Moqan was also carried out at that time. After those play-likes, other form of plays began to emerge in Iran amongst which Kooseh bar neshin (pre Islam), curtain plays, Nowrouzian plays and various types of traditional plays such as ma'rkeh giri (gathering people by different means) story telling (Naqali), and roo hozi plays were carried out as well (Jaffari, 1999, P: 28).

Naqali or story telling was a non-religious form of theater that has survived since the ancient times. Our knowledge of pre-Islamic story telling or naqali is restrained to descriptions mentioned in history and literary books such as Ferdows's "The Persian Book of Kings", ballads of Nezami Ganjawi, “The History of Sistaan", "The History of Bokhara" and Bin Nadim's "Al Fehrest". As mentioned in those books naqali or story telling of pre Islam era included telling the epic pre Islam stories by expert story tellers, this tradition found its way to the era of Islam and is the reason for the rhythmic edition of some Shahname's stories or stories such as "Veis and Raamin”, “ Khosrow and Shirin”, “Seven Minarets” etc (Alnazshakhi, 1972, P: 20-28). 
In Iran's history of theater a story teller or naqal is the most prominent figure. Some story tellers were amazingly skilled and could be considered as true artists.

Theater and playwriting in its European form does not have a long history in Iran. The art of theater always had a traditional sense in this country since many centuries ago. Shabih Khani or Ta'zieh (Theatrical form of mourning an Imam's martyrdom), puppetry, naqali and takht hozi were amongst the most popular plays performed in Iran.

The first half of the thirteenth century HQ was the time that Iran was introduced to the European form of theater. First, Iranian ignored this form of theater altogether, however they became more and more curioswith the passage of time, thus they began to analyze and study it in the second half of the thirteenth century HQ. This occasion had a long history before it though, since the Ottoman Turks prevailed the army of Shah Ismail Safavid at Chaldoran, the echoes of their cannons made Iranians who were brought up to mind their own business awake, thus they realized that there was a world beyond their land in front of which they deemed helpless. Therefore, they interest shifted toward the west. West, which had just came out of the renaissance and was supplied for despotism and was ready to colonize the Asian, African lands and the newly discovered continent of Americas .Then our inevitable European relationships with European powers such as England, France and Russia began in the Qajar era. When after Aqa Muhammad Khan's warfare to Tiflis Alexander Gribaydof, a playwright and Russia's autonomous Vizier to Iran was killed in Tehran, Abbas Mirza who was next in line for the thrown sent a groups of diplomats to Russia to offer Iran's apology, two months after that murder's occurrence. The Iranian diplomats' visit to Russia lasted for 10 months and 15 days, so the Iranians could investigate Russia's form of theater along with other investigations. In the travel journals left from that era the description of that journey and the theater palaces of Russia can be found. Two of the Iranian diplomats sent to that journey were secretaries named Mirza Taqi and Mirza Aqa. Mirza Tagi is actually the name of Amir Kabir who became Iran's Chancellor in the ruling era of Nasser Alddin Shah. He founded the school of Dar Al Fonoun (The place of Techniques), as a cultural center in which the first official Iranian plays were performed. As for Mirza Aqa, he probably is Mirza Aqa Tabrizi who later became one of Dar Al Fonoun's translators and tutors . and was able to acquire the playwriting style of Akhound Zade, he traveled to Europe during the reign of Nasser Alddin Shah numerous times, and was amazed by European culture and way of life. His visit to Paris's most famous theater made him determined 
to build a similar one in Iran, thus he ordered the building of a theater within the school of Dar Al Fonoun. However, since they did not have sufficient financial resources to build a huge theater palace and the society was not really ready to accept such things, the theater built in Dar Al Fonoun had only 300 hundred chairs. Mazin Al Doleh who was Shah's personal portrait drawer was amongst the first people sent to study abroad; he also contributed to building of Dar al Fonoun's theater and directed an adaptation of Moliere's play "Tartuffe". Amongst the plays written in accordance with Aristotle's principles were plays written by Mirza Fath Ali Akhound Zadeh, which were translated from Azerbaijani language to Farsi and were hugely celebrated. The mentioned translated works along with the works of Moliere and Gogol reinforced the art of theater and drama in this land. Mirza Aqa Tabrizi was so impressed by the works of Akhound Zade that started to send personal letters to him so he could get to know him better. Thereafter, what was introduced as theater in this land was hugely influenced by western drama and theater. In the last years of Nasser Alddin Shah's life, whispers of demands for more freedom started to grow amongst people. More newspapers were published and the wind of change was blowing bringing new demands with it. Finally, those whispers resulted in the constitutional revolution of Iran, with which Shah could not afford to fight, the promise of the better future made everyone's heart beat faster with hope.

When Iran's society was dealing with poverty, illiteracy and ignorance, all the world were experiencing monumental events, it was then that theater was introduced to people and they welcomed it with open arms, plays were able to entertain the folks and told them what they wanted to hear. Slowly, theatrical groups started to form in localities such a Tabriz, Rasht and other places as well. Iranian playwrights started to write about the current issues of society or following Moliere's comical plays, mimicked his style and mixed it Iranian talent and wrote Iranian style version s of his plays. As master Rashid Yasemi points out:” Some knowledgeable , decent folks who had filled both government jobs and were popular amongst peoples, left their official jobs and entered the world of drama and theater" ("The Contemporary Literature" Rashid Yasemi, P: 125).

\section{The Antiquity of Theater in Iran}

The antiquity of theater in Iran dates back to ceremonies known as mourning for Siyawosh and kin of Iraj in pre-Islam era. According to history books and also Shahnameh those ceremonies was carried out each year on a specific date. However, with the emergence of Islam costumes and 
religions of Gabarkans were not tolerated, and with the emergence of Shia'h Islam, Ta'ziah which is a ceremony for mourning Imam Husain's martyrdom replaced those ancient costumes Scholars cannot reach a consensus on the exact date for the emergence of ta'ziah. Some refer to Bin Kasir Shami's history and claim that ta'ziah's onset dates back to the ruling era of Dialameh (Mo'ez Al Douleh , 352 HQ ). However, another group of scholars believe that ta'ziah was started in Safavid era and what was performed before it, was some sort of a morning ceremony not a play-like one.

Still, ta'ziah was able to survive the passage of time and is still perfumed, however after the Qajar era and the emergence of modern theater it has lost its popularity thus it is only performed in small counties and god forsaken places. Even if it is performed nationwide on the occasion of mourning the martyrdom of Imam Husain its audience would consist of the lowest classes of society.

Naqali (story telling) and puppetry are amongst those non religious forms of plays which seem to be completely eliminated. The exact date for the emergence of naqali is also unknown, what we know for sure from the history and literary books such as Ferdows's "The Persian Book of Kings", ballads of Nezami Ganjawi, "The History of Sistaan", "The History of Bokhara" and Bin Nadim's "Al Fehrest, is that the story tellers or naqlas used to tell epic stories generation by generation a tradition that was able to found its way to the Islamic era as well and is the reason for the rhythmic edition of some Shahname's stories or stories such as "Veis and Raamin" , “ Khosrow and Shirin", "Seven Minarets" etc. Therefore there are numerous stories from the Islamic era which informs us about the history of naqali in that era. It is worth mentioning that some of those stories such as : "Samak Ayyar" , "The Story of Firouz Shah" "Darab Book of Beiqami”, "Darab Book of Tartousi" , "The Book of Iskandar" and “ Amir Arsalan” told by story tellers or naqalas have been recorded.

The art of naqali or story telling consists of reading or retelling epic events or romantic stories. In pre-Islam era it was accompanied by music, but since listening to music was forbidden in the religion of Islam, its non musical form grew and became prevalent. In the three Islamic centuries naqlas only retold the epic and national stories of Iran, however by the turn of the fifth century naqals started to make up stories themselves, and as you just read their stories were recorded the exact way that they have retold them. 
In the ruling era of Mongols, naqlai shifted toward epic-like legends and religious stories, in Safavid era naqali became hugely popular and its sub branches such as story reading, reading of Shahnameh, reading of Hamleh (Hamleh Heydari), retelling of eulogies and sermons etc were widely welcome by the folks. Naqali stayed popular throughout the Qajar era and with the emergence of cafes in Iran naqali became a fixed entertainment for café goers.

In Iran's history of theater a story teller or naqal is the most prominent figure. Some story tellers were amazingly skilled and could be considered as true artists. Their work is especially important since they have to capture the audience's attention and arouse their emotions by mere use of their hands and face expressions. And since naqali is all about entertaining, naqlas had to tell stories that would be intriguing for the audience to listen to.

Puppetry or puppet plays were another form of play-like ceremonies that were similar to today's theater with this difference that its actors were rag or wooden dolls, Actors whose movements were determined by a puppeteer.

There is not enough information about the origins of this form of play or whether Iranians were the ones who invented it or not. However, according to Nezami Ganjawi, puppetry was introduced to Iran since the time of Bahraam Goor.and was widely welcomed by Iranians.

Moreover, this form of theater did not get any chance to grow and transform, it is because big names of theater considered it a low form of entertainment which belongs to lowest classes of society, thus they did not do anything for its improvement, and therefore puppetry plays were not recorded. "The Bald Champion”, “Salim Khan”, “ The wedding of Salim Khan's Son”, “ Four Dervishes”, “ The Bald Hassan”. “ Bijan and Manijeh”, and “ The Paper Champion” are amongst the puppetry plays that had the chance to be recorded.

\section{The Ballads of Nezami}

Hakim Jamal Alddin Abu Muhammad Elias Bin Yusuf Bin Zakki also known as Nezami Ganjawi was born in Ganjah on the year 533 or 535 HQ. He lost his parents in his earliest years of childhood and grew up as an orphan, and his date of death has been reported as 599 or 607 HQ. Nezami got married several times in his lifetime, from which he was blessed with one son named Muhammad to whom he had left many advises (Reza Zadeh Shafaq, 1947, P: 299).

Nezami had sufficient knowledge about the popular sciences of his time (literary sciences, astronomy, Islamic sciences and the Arabic language), and his vast knowledge is evident in his body of work. His father's name was Yusuf and his mother was called Rai'ieseh. His grandfather 
was named Zakki and his great grandfather was known as Mo'yed. According to some sources he was born in Ganjah (a town in Azerbaijan Republic), but some sources claim his birthplace to be the town of Tafresh (a town in Iran's Markazi Province).

Just like other ancient masters, Nezami had a wide range of knowledge about all logical, literary, mystic and Arabic sciences. And knew all about the sciences of mathematics, natural and divine ones. His purity of heart and good character is rare in the history of Iran's poets. One cannot find even one single obscene word throughout his body of works and he never uttered a lewd verse in his lifetime. The old master of Ganjah has left us with six invaluable treasures in form of 5ive mathnawis , which have been mimicked by several poets disastrously. The mentioned six books are as follows:

"The Safe of Secrets', "Khosrow and Shirin,"Seven Bodies", "The Book of Honor and "The Book of Fortune", which testify to his knack for storytelling,

Although Nezami has written poems in form of odes and quatrain as well, but he is mostly famous for writing the poems of Khamsah or "Five Treasures" (The safe of secrets, Khosrow and Shirin, Laili and Majnoun, Seven Bodies and the Book of Iskandar) which are amongst the most invaluable Persian literary works . However, "The Ballad of Khosrow and Shirin" remains his best work among those mentioned above.

Nezami was a true pillar of Persian poetry, Him, along with poets such as Ferdowsi and Sa'die contributed to the creation and growth of a certain style. Even though the style of storytelling within a poem was not started with Nezami, but he remains the only poet who perfected this style by the sixth century.

Nezami's accurate choice of words, the rhythmic verses, use of creative compounds, invention of new and novel meanings, good description which derives from a strong imagination, accuracy in describing the natural sceneries, people and objects and the impressive use of metaphors and analogies are truly unique and matchless.

Despite Nezami's use of complex philosophical and Arabic phrases and also his word games in some verses, can be criticized, but his style is so heartwarming that would make him one of the greatest poets of Iran. I dare say that his style in describing the joyous moments is absolutely unique and matchless. His choice of words is so sweet and heartwarming that he has unconsciously enriched the description of the war scenes with his sweet and heart pleasing words. 
Nezami was the most famous writer of ceremonial stories. His "Five Treasures" has been mimicked by Iranian and Indian poet's numerous times. He contributed to the prevalence of romantic stories. The mathnawi of "The Safe of Secrets" in all its glory and purity has been written at the time of Mokhar Alddin Bahram Shah Da'ud the ruler of Arzanjan (who died on 622 HQ) about $570 \mathrm{HQ}$.

The ballad of Khosrow and Shirin narrates the story of Khosrow a Sassanid Shah who falls in love with a Christian girl named Shirin. Nezami finished this mathnawi by the year 576 HQ and dedicated it to Shams Alddin Abu Ja'far Muhammad Ildgaz Jahan Pahlawan (572-586). The plot to the story of Khosrow and Shirin has been written by Ferdowsi but it was Nezami who made it into an invaluable work of art:

A wise man told me this story one time

Narrated their love story one time

I didn't retell what the wise man said word by word

For it is not nice to repeat the words once told

(Reza Zadeh Shafaq, 1947, P: 26)

\section{Story's Summary}

Hormoz the Shah of Iran is blessed with a son whom he names Parwiz. Despite his father's just character Parwiz violates people's rights in his youth. One day he and his friends go to the country side for fun, at night, they drink and celebrate the night away in a home of a local man, in such way that their rowdy celebrations awakes the whole neighborhood, their behavior is in such way that even his servant and his horse fall victim to it.

When Hormoz finds out about this, he ignores their father and son relationship and serves the justice for his son: he kills his son's horse and gives away his servant and his royal throne to the owner of the garden whose property was trashed by him and his friends. However, Hormoz forgives his son through the intervention of older men of the locality. After this event, one night Khosrow dreams of Anooshirvan his grandfather in his sleep. In that dream Anoshirvan tells him that since he was not angered by his father's recent actions against him he would gain so much more than he had lost by this whole affair: a beautiful lover, a horse named Shabdiz, a glorious throne and a music player named Barbod. Shirin reaches Mada'en after going through a long way. But Khosrow was nowhere to be found. His servants welcomed her to the castle and took proper care of her, following Khosrow's instructions. When Shirin found that Khosrow has gone 
to Aran she became wary and upset. Her rivals put her in a mountainous area with an unpleasant climate where Shirin lived alone with the sad memory of Khosrow's love. The hands of fate had put Khosrow in a castle in which Shirin used to live once and her soft voice would echo in its every corner. However, the castle was now free of her smooth voice and the sound of her footsteps. Then Shahpour informs Khosrow about Shirin's journey to Mada'en and receives instructions from him to go there and bring her back. Thus, he goes to that mountainous place of bad climate and brings Shirin back to Aran. Upon her arrival she learns about Hormoz;'s death and becomes upset by it. Now that Hormoz is dead, the young Shah has to go to Mad'en to take his father's place. Thus, Shirin is unsuccessful in meeting his beloved yet again.

During the time of Khosrow's rule, a man named Bahram Choobin rebels against him and provokes others against him as well by accusing him of patricide. Afraid for his life Khosrow runs away to Mooqan. Aongst all this craziness, one day he goes hunting with his friends and meets Shirin who was there for the intention of hunting as well. The lovers reunite after so many years, and at a time that Khosrow has lost the crown and throne of kingdom. Then, Shirin invites Khosrow to the castle of Mahin Banu. Mahin Banu, who is aware of the history of their love affair , asks Shirin not to ever talk to Khosrow in private and Shirin swears to honor her wish.

Even though, Khosrow and Shirin enjoyed each other's company in hunting and at ceremonies, but Khosrow never found the chance to make love to her beloved. Finally, after begging her for some time and encountering her refusal, Khosrow became weary and left her lover for Rome. There, he married Mari'am the daughter of the King of Rome then attacked Iran after a while and claimed his throne back. However, he still missed Shirin and could not tolerate to be away from her. Shirin was also restlessly missing her beloved.

Mahin Banu, who was now in her death bed advised her niece to be patient because she had learned from her life experiences that both happiness and sadness are temporary states on which one should not depend.

After Mahin Banu's death, Shirin gains her throne and becomes a just and righteous queen. However, she was still missing her beloved Khosrow very much. Thus, she puts one of her trusted men in charge and leaves for Mad'aen to see him.

One day while Khosrow was celebrating he learned about Barham Choonbin's death, thus he stalled his celebrations for three days only to start it afresh on the fourth. Then he asked for Barbod because the songs played by helped Khosrow tolerate the pain of separation from Shirin. 
One day Farhaad (also in love with Shirin) goes to the mountains and starts carving the pictures of Shirin, the Shah and Shabdiz on the mountain. Then he continues digging the mountains thinking of his beloved Shirin. The story of his mountain digging gains a universal fame. One day Shirin goes to that mountain with her horse and brings him a bowl of milk. On her way back, her horse becomes stuck in the mountains and puts her life in danger of falling. However, Farhad rescues her and her horse, puts them on his shoulders and takes them back to the castle. This story and also the story of Farhad's strength to dig the hard stone reaches Khosrow's ears who has lost hope in possessing Shirin and tries to come up with a solution. Advised by his counselors, he sends a group of messengers to Farhad to tell him the false news of Shirin's death , so maybe he would be disappointed in his quest and give up. Upon hearing this false news, Farhad puts his digging tool down and drops dead. Shirin becomes very upset by the news of his death and orders her men to build a minaret upon his grave. Meanwhile, Khosrow sends a comical condolences letter to Shirin and advices her to stop grieving. After a while Mar'yam Khosrow's wife passes away and Shirin answers Khosrow's letter saying she doesn't care about losing pretty faced men for many more are at her service. Khosrow, reads her answer and realizes that his insensitive letter truly deserved such answer. He made several other attempts to possess Shirin but none of them worked and she remained out of reach to him. Disappointed again, he went to Isfahan in search of a woman named Shekar (Sugar) whose beauty he had heard so much about. However, even having Shekar could not quench his desire for Shirin. Aware of Shahpour's closeness to Shirin, Khosrow asked him to his castle , so maybe Shirin would feel lonely and come to seek her companion in his castle. However, Shirin cried of loneliness but still carried on with her life. One day, Khosrwo, went near Shirin's place with the excuse of hunting. Shirin send a servant to welcome him and placed him in a dwelling nearby. Angered by this sort of treatment, Khosrow complained to Shirin and begged to be intimate with her, still Shirin refused and told him he can only get her by following traditional rules. After a long conversation with Shirin, Khosrow comes back to his palace. With Khosrow's departure, Shirin feels lonely and sad again. Thus, he goes to his place and by the help of Shahpour hides somewhere nearby. At dawn Khosrow throws a celebration. Shirin hides in a corner of the room. In this ceremony Nik speaks for Shirin and Barbod speaks for Khosrow. After a while Shirin becomes restless and comes out of her hiding place. Overwhelmed by seeing Shirin in his own castle, Khosrow becomes excited and asks the older men of the locality to ask for her hand in marriage for him. 
When finally his dream of intimacy with Shirin comes true, he gives away his throne to Shahpour and goes to Aran with his wife. Also, he listens to Shirin's advice for establishing justice and educating himself. While learning science, one day he asks lots of questions about the positions of the stars and planets the origins of creation the afterlife etc from his tutor Bozorg Omid. After a while, Khosrow who is aware of the evil nature of his own son Shirouieh gives his throne to him by the advice of Bozorg Omid and dwells in Atashkhaaneh himself. Upon gaining power, Shiroieh imprisons his father and only allows Shirin to visit him. Her presence made the imprisonment tolerable for Khosrow. One day when Khosrow was laying next to Shirin an unknown person came to the room and injured him with a dagger. Afraid to awaken his beloved, he died without making any sound. Alarmed by a bed wet with blood Shirin woke up and found his beloved's body motionless; and let out a sad cry. While she was grieving his beloved's death, Shirouieh asked for her hand in marriage a request which Shirin decided not to acknowledge with any kind of response. At dawn when Khosrow's body was taken away, Shirin in all her glory went to the place they put him, put the dagger in her heart and died laying beside Khosrow. Saddened by this whole, affair, the eldest of the country buried them both in that place.

\section{THEATRICAL ADAPTATIONS OF "THE BALLAD OF KHOSROW AND SHIRIN"}

Nezami wrote this ballad in honor of his beloved first wife "Afaq'. At the end of this ballad, where Shirin is grieving Khosrow's death, he has mentioned the name of Afaq (Nezami, 1994, P: 326).

As you read, Naqals or story tellers usually had the responsibility of narrating such stories. However, Iranian playwrights started to adopt the mentioned stories into plays as well. The first attempts to do so was made in the era of constitutional revolution, and the greatest motive for doing so was the presence of strong dramatic elements in the Persian ballads, such as : Shahname's stories, Nezami's Khamsah and other literary works. Despite their popularity amongst theater critiques balladic plays were not popular among ordinary audiences due to their playwrights' inability to use the poetic language in an effective way in order to capture audience's attention. However, those early attempts paved the way for successful adaptations, amongst which Kazem Zadeh Iranshahr's adaptation of "The Story of Rustam and Sohraab" is worthy of mentioning. 
The very first theatrical adaptation of a ballad was named "The Fate of Parwiz" which was written by Ali Muhammad Khan Oveisi in 1945. He had adopted this play from the ballad of “Khosrow Parwiz” by Nezami Ganjawi (Malek Pour, 1984, vol.2 P: 233).

However, "The Fate of Parwiz" was not Ali Muhammad Khan's independent work. He had adopted it from the ballad of "Khosrow Parwiz" and added his own scenes and pieces to it. This play was the first acceptable attempt to adopt a ballad; however the playwright's poems could not be compared with the ones in the original work. His poems were weak and could not transfer the mode of the play to the audience. On the other hand, Oveisi had overlooked the theatrical elements that are so important for writing a strong play. Therefore, his work lacks the attraction which most dramatic plays posses. Action is completely missing from the play of "The Fate of Par wiz". Unpredictability which is also an important factor in plays is also missing from it. The characters of this play do not utter even one unpredictable sentence that would intrigue the audience's curiosity. This play only possesses some aspects of a theatrical work such as dialogues, time and date correspondence and a certain subject which any elementary theatrical work should possess,. However, since it is the very first adaptation of a ballad into a play, its weakness can be overlooked. The first act of this play starts with Khosrow Parwiz's conversations with Shirin about his horrible nightmares in which he had seen the demise of his and his family's kingdom. Next, we see the Arab Messenger who gives him the Noble Prophet's letter in which he has invited Parwiz to convert to Islam, something that upsets Khosrow Parwiz even more. It is in this act that we found out about Khosrow's reluctance to give up his throne to his son Shirouieh. The play has more theatrical attraction in its second act in which Zoroaster comes to Khosrow Parwiz's dream and Khosrow informs him of the demise of the country. When Khosrow wakes up from that dream Shirouieh kills his father with a dagger, Shirin comes to his dead husband's side crying and commits suicide there. Generally the playwright does not seem to take a stable stand and he does not specify who is actually to blame for the country's demise. He has described Khosrow as a great king somewhere and has scolded him as a ruthless pleasure seeker somewhere else.

Other adaptations of this play consist of the play "Shirin and Farhad" directed by Asgar Qods in 1987 or the play :" A Fringe Version of Khosrow and Shirin" which was performed for the first time in the 20th Fajr International Festival of Theater in 2001 and won the especial juries' award 
of that festival. Dariush Ra'yat the playwright to this play had used a different approach toward the concept of love an approach that had modern elements within it (Kangarani, 2011, P: 19). Turkish playwright Nazim Hekmat had also adopted "The Ballad of Khosrow and Shirin "into a play named "Shirin and Farhad". What is interesting is that this ballad is popular in other countries with various cultures as well. The summary of Hekamt's play is as follows: Mahin Banu, who is very fond of Shirin, sacrifices her beauty for the well being of her. Then she builds a castle for her, but when it is ready, both sisters encounter the painter of the castle named Farhad and fall in love with him. Shirin attracts Farhad's attention by throwing an apple at him. They run away together but Mahin Banu finds and arrests and bring them back to the castle. At this point Mahin Banu asks Farhad that if he is willing to go the mountain of Biston and dig it in a way that a spring would come out of it for the use of town's people merely out of his love for Shirin? Because the town's water supply is not hygienic and drinking it makes people ill and kills them. Farhad accepts the challenge and leaves Shirin behind for the mountains.

In the second act, people decide to visit Farhad the stubborn man of love, after eleven years. In this act Shirin goes to him as well and asks for his hand in marriage an offer which he refuses for he is not done honoring his promise, thus Shirin leaves his beloved and goes back (Hekmat, 1967, P:80-83). Nazim Hekmat has changed Nezami’s story completely and has made up a new one out of it. He has transformed all the aspects of the ballad such as its characters, theme and subject. In Nezami's original work, Shirin is not in love with Farhad, but in the play Shirin's love belongs to him. Farhad's character also differs from Nezami's Farhad and does not have the restlessness and dreaminess of his version. In this play, Farhad honors his promise and values the completion of his mission more than being intimate with a woman he loves. The use of apple in this play, symbolizes the very first love affair between Adam and Eve. Therefore, it is fair to say that Hekmat has hardly used the chief aspects of Nezami's original work in his play. In most adaptations of this ballad the tragic aspect of it that is, the patricide of Shirouieh and Shirin's suicide has been excessively dramatized. It is because the playwrights can use this sensational scene in order to write their most impressive dialogues and portrait this tragic love affair in a way that would provoke the audience's emotions. However, other parts of "The Ballad of Khosrow and Shirin" have the potential of attracting attentions as well and could be good materials for writing high quality plays, because Nezami has done his best to show off his skills describing the 
natural sceneries, hunting scenes, the inner emotions, lovers' state of mind, separation, the enthusiasm for reunion and romantic complaints and laments.

\section{CONCLUSION}

The story telling literature can be defined as a form of literature with literary works that are suitable to be perfumed in theaters or other places, and consists of plays, scenarios, books of Ta'ziah etc.

The ancient forms of Persian plays were rooted in religious teachings. The earliest forms of plays were the Zoroastrian ceremonies in which Maqs would gather and sing the songs written in the Avesta while dancing in groups. In ancient Persia, theater-like ceremonies were carried out in the occasion of mourning and victory, such as Kin Syawosh which was a ceremony in honor of Syawosh's death carried out in the north east localities of Iran until the fourth century, other ceremonies in that form such as Kin Iraj, Mourning for Zaal, Jamshid Religion and crying for Moqan was also carried out at that time. After those play-likes, other form of plays began to emerge in Iran amongst which Kooseh bar neshin (pre Islam), curtain plays, Nowrouzian plays and various types of traditional plays such as ma' rkeh giri (gathering people by different means) story telling (Naqali), and roo hozi plays were carried out as well. All the mentioned ceremonies would only appeal to the lowest classes of society and did not need a written play. The only form of early theater that did have certain scripts was Ta'ziehs. Ta'zieh which is performed since the era of Mo'ez Al Douleh Deilami in mourning ceremonies till the Safavid era was able to survive till this day and age.

Meanwhile, classic Persian poems and prose works had always attracted the attention of playwrights, and the writers of movie scenarios. Khosrow and Shirin is amongst those notable literary works. It was first adopted into a play in the era of Iran's constitutional revolution. Others have adopted in into different plays as well and has always been used a model for play writing. The tragic aspect of this story which narrates the story of Shirouieh's patricide and Shirin's suicide has always been interesting to writers; some adaptations of this ballad have changed the whole frame work of its story and transformed its characters, while some were loyal to the original text. However, it is worth mentioning that all the aspects of Nezami's ballad have the potential to be turned into a play since Nezami had described the natural sceneries, hunting scenes, the inner emotions and lovers' state of mind, separation, the enthusiasm for reunion and 
romantic complaints and laments of lovers in the best way possible. Moreover, despite numerous attempts to adopt these classic works of art into plays but there is still a long way for the full introduction of their higher concepts and this is due to the high capacity of them, a capacity that has not been analyzed with a deep and investigative eye yet.

\section{REFERENCES}

1. Alnarshakhi, Abu-Bakr , 1972, “The History of Bokhara”, written by: Muhammad Bin Zafar Bin Omar, edited by : Moddares Razavi, Farhang Iran Publications, Tehran

2. Aristotle, "Rhetoric of Aristotle" translated by : Abdullah Mojtabani, Nasre e Andisheh Publications, Tehran

3. Bin Nadim , Muhammad, 2009, “ Al Fehrest” translated by Muhammad Reza Tajaddod, Asatir Publications, Tehran

4. Beizaie, Bahram, 2013, “ Theater in Iran” Roshanfekran Publications , Tehran

5. Browne, Edward, 1877, “ A Literary History of Persia” Amirkabir Publications, Tehran

6. Ja'fari , Muhammad Reza, 2008, “ The Persian Literature Dictionary”, Farhang Nashr Now Publications, Tehran

7. Ashourpour Sadeq, 2010, “Naqali: a Portrait of Persian Shahs” Soureh E Mehr Publications , Tehran

8. Saffa , Zabih-Allah, 1990, “The Literary History of Persia” 2 vol. Ferdows Publications, Tehran

9. Kangarani , Manijeh , 2011, "Shirin in the Contemporary Mythical Dialogue", Honarhay E Zibaa Magazine, no.43

10. Mir Sadeqi, Jamal, 1985, “Story’s Elements” Safa Publications, Tehran

11. Malek Pour , Jamshid, 1984, “ Theatrical Literature of Iran” Tus Publications, Tehran

12. "Nould Ke" 2005, Translated by Bozorg Alavi, Negah Publications, Tehran

13. Nezami, Abu Muhammad Elias, 1988, “Khosrow and Shirin”. With the prologue of Muhammad Ayati, Elmi Farhangi Publications, Tehran.

\section{How to cite this article:}

Amiri M,. Adaptation of theatrical elements of nezami ganjawi: a case study on the ballad of khosrow and shirin. J. Fundam. Appl. Sci., 2016, 8(3S), 833-854. 